\title{
A Study on the First Grade Students' Understanding of Personal Pronouns in English Reading Texts at SMPN 1 Singingi
}

\author{
Fanny Laina Tussifa ${ }^{1}$, Harum Natasha ${ }^{2}$ \\ Faculty of Education and Teacher Training, \\ State Islamic University of Sultan Syarif Kasim Riau, \\ Pekanbaru, Riau, Indonesia \\ $\underline{\text { Fanny.lainatussifa09@gmail.com }}{ }^{1}, \underline{\text { harum.natasha@,uin-suska.ac.id }}^{2}$
}

\begin{abstract}
The problem of this research was to know how well the students' of SMPN 1 Singingi in Understanding personal pronouns in a text at SMPN 1 Singingi is. The research was conducted at SPMN 1 Singingi from Februari $3^{\text {rd }}$ to Februari $27^{\text {th }}$, 2021. The population of this research was 40 students of two classes and researcher took 20 students as the sample. This research was quantitaivedescriptive research. Researcher used fill-in-the-blank text test to collect the data. In analyzing the data, researcher collected and classified each item of the test and multiplied them by standardizing the scores that had been determined before. The next step was counted the percentage of the level of the students' ability in using personal pronouns. From the research findings, researcher found that the test was gained 1545 from total scores of all the students who joined the test. The average of students' scores was 77.25 and the sum of the total scores was 85\%. It means that most of the students did well on the test and understood personal pronouns in reading text.
\end{abstract}

\section{Keywords: Study, Understanding, Personal Pronouns}

\section{INTRODUCTION}

Nowadays, English becomes an essential language subject to education issues in Indonesia. Indonesian students learn English from elementary school up to university. By learning the English language, they wish they can communicate well, and become more confident in English. Many young learners face difficulties to understand
English as their second language, which is different from their language, Bahasa.

In learning English, there are certain skills that students need to learn, namely: listening, speaking, reading, and writing. Listening and reading skills that involve receiving messages are regarded as receptive skills. Speaking and writing skills that involve language production are considered to be productive skills. Reading can be thought of as a way to 
draw information from the text and to form an interpretation of that information. However, this statement does not tell us much about what happens when readers are reading and how to comprehend a text. Sometimes, students may know most of the vocabulary and understand the main concept of a text, but they may not follow the specific development of the text, new information being presented or the arguments being made.

According to Rosniati Lubis in Scanlon (2010 p.9), reading is a complex process that requires analysis, coordination, and interpretation of a variety of sources of information. While Urquhart \& Weir in William Grabe (1998 p.22) define reading as the process of receiving and interpreting information encoded in language from the medium of print. Reading becomes important because it will bring some advantages. By reading, students will gain a lot of information from various sources that can add their insights to the world and its development.

They also get more additional knowledge that has not gained from the teacher's explanations at school. The information that is obtained can be important information that they need to know. Moreover, about everything that happened or something they do not know before, which will enrich their knowledge about everything. Sometimes, reading is seen as a simple activity, but actually, it is a complex activity. It is not just spoken of symbols that form of writing but also to understand the purpose of the text. In reading, students are expected to observe, understand and think. In conclusion, the readers should be able to understand the message by the author.

Based on the preliminary research at SMPN 1 Singingi, many students have difficulties in analyzing reading comprehension. First, students still used their traditional reading way, that is, still focus on printed symbols (words), finding difficult words. Second, they also did not know how to use the personal pronoun, but it occurred without understanding the meaning. Third, some students have tried to comprehend the text by reading it many times but they failed because they did not know its meaning. So, students could not find good impressions from the text they read and they did not know what they read for.

In some cases, students may not be fully familiar with the overall genre expectation of certain types of texts. Students recognize and are aware that something is not working the way they expect, but they do not know why. Reading is a skill which is highly valued by students and teachers alike. Students almost get texts in their studies. The text can be difficult or easy, depending on the factor inherent in the text, on the relationship between the text and the knowledge and abilities of the reader, and on the activities in which the reader is engaged. The text in reading material can be articles, advertisements, folktales, myths, legends, hero tales, or short stories that can be found easily in newspapers or magazines.

Based on the interview, the researcher concludes that there are two problems students' faces in understanding personal pronouns. First, students have difficulties understanding personal pronouns in their English sentences and it is difficult to place them. Second, when students have already understood personal pronouns, they are still confused about the time, when they should use the subject or object pronoun. Because of that, many grammatical errors are made by the students. Based on this reason, the researcher chooses the personal pronouns as the main topic of 
this research, because the students are still confused to differentiate between subjects and object pronouns

Furthermore, when the teacher explains the English material in front of the class, mostly the students pay attention to the teacher's explanation. But the problem is the students do not understand what the teacher has explained. It is because the students have low skill in English vocabulary that when there is a changing of the word based on the context makes the students really confused and not really understand about the material. In the classroom, for example, the class has 25 students, students who understand the material were less than 15 persons, while the rest students will not really understand the material.

Based on the problem depicted in the background, the researcher formulates some research questions as follows: How well are the students of SMPN 1 Singingi in understanding personal pronouns in a text?

\section{LITERATURE REVIEW}

\section{a. The Nature of Descriptive Text}

According to Corbett (1983), descriptive text is one of the expository writing. The description draws a picture, tries to convey the sound, taste, and smell of things or objects. Tompkins (1994) and Stanley (1988) states that descriptive text is like painting pictures with words. By reading a descriptive text, readers feel that they see the description just like they see pictures. The descriptive text has the purpose to describe an object or a person that the writer is interested in.

Friedman (2010) defines that descriptive details mean to grab the reader's attention. A descriptive text is considered as the simplest and easiest writing form compared to narrative, recount, or procedure, particularly for the beginning writers. Furthermore, a descriptive text is considered as the simplest and easiest writing form compared to the narrative, recount, or procedure, particularly for the beginning writers (Ellis et. al., 1989). It allows students to share interesting impressions of a person, a place, or an object surrounding them (Troyka, 1987).

The researcher defines descriptive is a text contently with basically describe something in a text with a generic structure.

\section{b. Nature of Pronoun}

Ebbits defines that (1978 p.521), grammar may also refer to the capacity of mind. The ability of every normal human being possesses to speak and understand sentences. Thus, we all have grammar in overheads. Every human being understands an indefinite number of new sentences he has never heard before. The study of grammar is the study of arrangements of the word into a more or less meaningful group. To study needs to know how words are related to each other, or use the terms introduced earlier to learn how to construct a signal system which will make effective and efficient communication.

Hornby (1991) says that a learner who wishes to speak and write English correctly must be concerned with grammatical correctness. It means grammar is a very important role in studying English. In grammar, we should learn about tenses, adverbs, prepositions, conjunction, verb, adjective, noun, and pronouns. Eckersley (1980 p.91) says that pronoun is one of the parts of speech. The pronoun is the word used in a place of noun or noun phrase, such as he, me, them, and hers. Pronouns are a 
structured class whose members serve as substitutions forms noun phrases. The noun phrase for which a pronoun substitute is called the antecedent of the pronoun. The subcategories of pronouns serve as substitution forms to different degrees.

Abia in Nkopuruk (2013 p.2) sees the Pronoun as those words used in place of the nouns to avoid unnecessary repetition. In other words, a Pronoun is a grammatical item used in substitute for a noun or noun group.

Example: The two hungry teenage boys are eating apples.

They are eating some apples. Word "they" replaces a noun phrase "the two hungry teenage boys".

John admired the woman who dared to stand up against the dictator.

John admired her. The word "the woman who dared to stand up against the dictator" is substituted with the word "her".

a. possessive pronoun

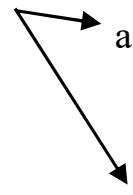

as pre modifier of the noun phrase: my, our, your, her, its, their

as head of a noun phrase: mine, ours, his, hers, theirs, yours Example: This pen is mine. "Mine" is ownership of "this pen". I wash my car every day. "My" must be accompanied by a noun "car" because it cannot stand alone.

b. Demonstrative pronoun: this, that, these, those

Example: Some new historical fossil books have been in the library.

Those books often are inquired by students and lecturers.

A blue small pen was left out of the class.

This pen is mine. c. Reflexive pronoun: myself, ourselves, yourself, himself, herself, itself, themselves

Example:

I myself will personally see to it. "Myself" is for emphasis the sentence, the pronoun is as a post modifier.

The boy blamed himself. "Himself" refers to the subject "the boy".

d. Interrogative pronoun: who, whom, whose, which, what

Example:

What would you like to have for lunch?

Which do you pick?

Which chair did you pick?

\section{a. Personal Pronoun}

According to Mellie and Panlene (1976 p.287), personal pronouns are ones that show their forms, whether they refer to the speaker, those spoken to or those spoken about. Michael Swam (1995 p.431) says personal pronouns are used when it is necessary to use or repeat a more exact noun phrase. English that is commonly used today has seven personal pronouns, they are:

a) First-person singular (I)

b) First-person plural (we)

c) Second-person singular and plural (you)

d) Third-person singular human or animate female (she)

e) Third-person singular human or animate male (he)

f) Third-person singular inanimate (it)

g) Third-person plural (they) 
The form of personal pronoun depends on the function of the personal pronoun itself. The subject and object personal pronoun can be seen in the following table:

Table 2.1

\begin{tabular}{|r|r|r|r|r|}
\hline Subject & Object & $\begin{array}{r}\text { Possessive } \\
\text { Adjective }\end{array}$ & $\begin{array}{r}\text { Possessive } \\
\text { Pronou } \\
\text { n }\end{array}$ & Reflexive \\
\hline I & Me & My & Mine & Myself \\
\hline You & You & Your & Yours & Yourself \\
\hline She & Her & Her & Hers & Herself \\
\hline He & Him & His & His & Himself \\
\hline It & It & Its & & Itself \\
\hline We & Us & Our & Ours & Ourself \\
\hline You pl. & You & Your & Yours & Yourself \\
\hline They & Them & Their & Theirs & Themselves \\
\hline \multicolumn{5}{|c|}{ Neutral reflexive - oneself or one's self } \\
\hline
\end{tabular}

From the table above, it can be explained that speech naturally presupposes people, they are: a person who speaks and a person who is spoken to (Eckserley, 1973:97) in other words, the word "l" and "we" are pronoun of the first person. "l" is called the first- person singular form, while "we" is called the first person of plural form. "You" is the pronoun of the second person. Beyond these two persons, person or things that are spoken about are called the thirdperson plural form; they are "he, she, and it. And "they" are called the third- person singular forms.

Example:

Incorrect: John is my teacher. John is in the classroom

Correct: John is my teacher. He is in the classroom.

Incorrect: Tia needs a book. She needs a book to read.

Correct: Tia needs a book. She needs it to read.

Incorrect: Iwan is my friend. Iwan is at my house.

Correct: Iwan is my friend. He is at my house.
Incorrect: Andi and Rian play volleyball. Them plays volleyball every afternoon.

Correct: They play volleyball every afternoon.

Personal pronouns have two forms they are personal pronoun as subject and personal pronoun as the object. Personal pronouns as the subject are I, You, We, They, She, He, And It. And personal pronouns as objects are Me, You, Our, Them, Her, His, and It.

\section{b. Subjective Pronouns}

A subject pronoun acts as the verb. It acts as the subject of a sentence. William (2005 p.62) argues "When a noun or pronoun is functioning as a subject, it is in the subject in a sentence. It is a pronoun form to substitute a noun or a noun phrase as subject in a sentence. It can be a place, person, thing, event, substance, or quality. There are seven types of subjective pronouns. They are I, you, we, they, she, he, and it. I, you, she, he, and it, are included in the singular form. They are used to replace the named person or a noun. Especially, she and he are used to a specific appearance. She is used for a feminine appearance, for example, mother, sister, aunt, and names female. He is applied to a masculine appearance. For example, father, brother, uncle, and names male.

Example:

a. A feminine appearance:

Luna is a good athlete.

She is a good athlete.

(The pronoun she replaces

Luna)

The tall young lady is making so noisy.

She is making so noisy.

(The pronouns she replaces the 
tall young lady)

b. A masculine appearance: Your brother was sick. He did not come to class. (The pronoun he replaces your brother)

John invites watching movies tonight.

He has a good new movie. (The pronoun he replaces John)

They and we are included in a plural form that used to replace nouns or noun phrases as a subject in a sentence.

Example:

a. They

The beans and tomatoes are fresh-picked.

They are healthy food. (The pronoun they replace the beans and tomatoes)

The smart young children win the science competition.

They win the science competition.

(The pronoun they replace the smart young children)

b. We

My friends and I want to go to the beach next week.

We want to spend our time there.

(The pronoun we replace my friends and I)

My families go to a restaurant once a week.

We go to a restaurant once a week.

(The pronoun we replace my families)

Especially for the pronoun "you"e, it can be included in singular or plural form. It is included in singular form when "you" is used to substituting in singular noun or noun phrase, and "you" is included as plural form when it is placed in plural noun or noun phrase. Therefore, we can use subjective pronouns as a subject in a sentence to make it clear.

Example:

I am asked to meet Ms. Rina.

Rani says that you should come to Ms. Rina's room.

The pronoun you is the indirect sentences is a singular form because you refer to me.

Both of the children were asked to be silent because of a special guest coming. Mother said that you asked to study hard tonight.

The pronoun you is the indirect sentence which replaces both of the children is a plural form.

\section{c. Objective Pronouns}

An objective pronoun acts as the object of a sentence. Williams (2005:62) states "When functioning as an object, it is in the objective case". It receives the actions of the verb. An objective pronoun is used to replace a pronoun of a noun or noun phrase as an object. It can be a plant, thing, living animal, or a person. There are some kinds of objective pronouns. They are me, you, him, her, it, them, and us.

$\mathrm{Me}$, you, him, her, and it belong to singular form while they and us are counted on the plural form. All of them are placed as an object in a sentence because they are affected by an action. Besides, the existences always are affected by verbs so that an object relates to the verb. The function of objective pronouns can be as a direct object and an indirect object. Example:

a. A direct object

They invited me last week.

John speaks to you.

The money was given to us. 
b. An indirect object

My mother gives me the money. Marcel talked them all to the circus.

They tell her a horror story.

From the examples, we can say that a direct object is an object which receives the action of the verb directly. Moreover, an indirect object is an object which receives the action of the verb indirectly.

\section{METHOD}

The design of this research was a descriptive quantitative method because the data was presented in numerical and descriptive form. According to Sugiyono (2012 p.13), descriptive research is research conducted to determine the value of the independent variable, either one or more variables (independent) without making comparisons or making correlations with other variables.

Quantitative methods emphasize objective measurements and the statistical, mathematical, or numerical analysis of data collected through polls.

The participant of this research was the first-grade students of State Junior High School 1 Singingi, Regency of Kuantan Singingi.

The researcher conducted this analysis on data from the sampled clusters. In this research, the researcher took 20 students as the sample to analyze the personal pronouns in 20 students as the sample to analyze the personal pronouns in reading text. The sample of this research was the students in class VII.1. Class VII.1 was the representation of the entire population and researcher randomly selecting and sampling from clusters.

The instrument of this research was a test to analyze students' mastery in grammar, especially about personal pronouns. The test was constructed based on the text, which consisted of 2 texts. The first text consists of 13 items, and then the second text consists of 7 items. So, there were 20 questions for this research. The material of the test was taken from the students' English book for junior high school and English Pronoun Worksheet. The test was administered in 45 minutes. The first 30 minutes was used to answer the questions and the rest was used to read the text. According to Harris (1969 p.64) in answering the reading test, one minute is enough for one item.

\section{FINDINGS AND DISCUSSION}

To collect the data, the writers used a test. The test referred to the students' ability in using personal pronouns in reading text. Before giving the test to the students, the researcher tried out the test in order to know the students' level in understanding personal pronouns. The researcher tried it out for the first-grade students of SMPN 1 Singingi.

a. Test

The test was an essay of using personal pronouns which the test was guided by the researcher. The students needed to circle the correct pronoun in the text or the students only had to follow the instructions given. The students had some questions dealing with using personal pronouns, they consisted of 2 texts. The first text consists of 13 items, and then the second text consists of 7 items. In order to arrange the items of the test, the writer worked based on text that was taken from the students' English book for junior high school and English Pronoun Worksheet. There were 20 students who joined the test, and students' scores were taken from 
individuals' correct answers. For the students who were able to answer each item accurately, the writer gave score 5 (five) for each item and for those who did not complete them got 0 (zero). Therefore, the students should answer all of the items as well as their own understanding about using personal pronouns as subject and object.

Table 4.1

Students Score of a Study on the First Grade Students' Understanding of Personal Pronouns in English Reading Texts at SMP N 1 Singingi

\begin{tabular}{|l|l|l|l|}
\hline Students & Score & Classification & $\begin{array}{l}\text { Bench } \\
\text { marks }\end{array}$ \\
\hline Student 1 & 80 & Very Good & 68 \\
\hline Student 2 & 95 & Very Good & 68 \\
\hline Student 3 & 70 & Good & 68 \\
\hline Student 4 & 90 & Very Good & 68 \\
\hline Student 5 & 75 & Good & 68 \\
\hline Student 6 & 85 & Very Good & 68 \\
\hline Student 7 & 85 & Very Good & 68 \\
\hline Student 8 & 90 & Very Good & 68 \\
\hline Student 9 & 90 & Very Good & 68 \\
\hline Student 10 & 90 & Very Good & 68 \\
\hline Student 11 & 90 & Very Good & 68 \\
\hline Student 12 & 80 & Very Good & 68 \\
\hline Student 13 & 70 & Good & 68 \\
\hline Student 14 & 75 & Good & 68 \\
\hline Student 15 & 70 & Good & 68 \\
\hline Student 16 & 65 & Enough & 68 \\
\hline Student 17 & 55 & Less & 68 \\
\hline Student 18 & 70 & Good & 68 \\
\hline Student 19 & 45 & Less & 68 \\
\hline Student 20 & 75 & Good & 68 \\
\hline SUM & 1545 & - & - \\
\hline
\end{tabular}

Based on the table above, the researcher found the classification of students' tests where 10 students got "Very Good", 7 students got "Good", 1 student got "Enough" and the rest got "Less". It meant that based on the benchmark of SMPN 1 Singingi only 17 students passed the test of understanding personal pronouns consisting of 2 texts and they were 20 items. Furthermore, the researcher concluded that the first-grade students at SMPN 1 Singingi understood about personal pronouns in the text, especially in reading skill.

Table IV.1

Students Score of a Study on the First

Grade Students' Understanding of Personal Pronouns in English Reading Texts at SMP N 1 Singingi

\begin{tabular}{|c|c|c|c|}
\hline Students & Score & Classification & $\begin{array}{c}\text { Bench- } \\
\text { marks }\end{array}$ \\
\hline Student 1 & 80 & Very Good & 68 \\
\hline Student 2 & 95 & Very Good & 68 \\
\hline Student 3 & 70 & Good & 68 \\
\hline Student 4 & 90 & Very Good & 68 \\
\hline Student 5 & 75 & Good & 68 \\
\hline Student 6 & 85 & Very Good & 68 \\
\hline Student 7 & 85 & Very Good & 68 \\
\hline Student 8 & 90 & Very Good & 68 \\
\hline Student 9 & 90 & Very Good & 68 \\
\hline Student 10 & 90 & Very Good & 68 \\
\hline Student 11 & 90 & Very Good & 68 \\
\hline Student 12 & 80 & Very Good & 68 \\
\hline Student 13 & 70 & Good & 68 \\
\hline Student 14 & 75 & Good & 68 \\
\hline Student 15 & 70 & Good & 68 \\
\hline Student 16 & 65 & Enough & 68 \\
\hline Student 17 & 55 & Less & 68 \\
\hline Student 18 & 70 & Good & 68 \\
\hline Student 19 & 45 & Less & 68 \\
\hline Student 20 & 75 & Good & 68 \\
\hline SUM & 1545 & - & - \\
\hline
\end{tabular}

Based on the table above, the researcher found the classification of students' tests where 10 students got "Very Good", 7 students got "Good", 1 student got "Enough" and the rest got "Less". It meant that based on the benchmark of SMPN 1 Singingi only 17 students passed the test of understanding personal pronouns consisting of 2 texts and they were 20 items. Furthermore, the 
researcher concluded that the first-grade students at SMPN 1 Singingi understood about personal pronouns in the text, especially in reading skill.

\section{DATA ANALYSIS}

In analyzing the data, a technique quantitative descriptive by percentage was used in this research. The data analysis was meant to know the ability of the first-grade students of SMPN 1 Singingi in understanding personal pronouns in a text. In doing this research, the writer administered a written test to the first-grade students of SMPN 1 Singingi. The first step in getting a quantitative analysis result was by collecting and classifying each item of the test and multiplying them by standardizing the scores that had been determined before. The next step was counted the percentage of the level of the students' ability in using personal pronouns.

To know for the detail difference, the each score of the test of the students in personal pronoun was described the result in histogram below:

Figure 4.1

Range Score of the Test

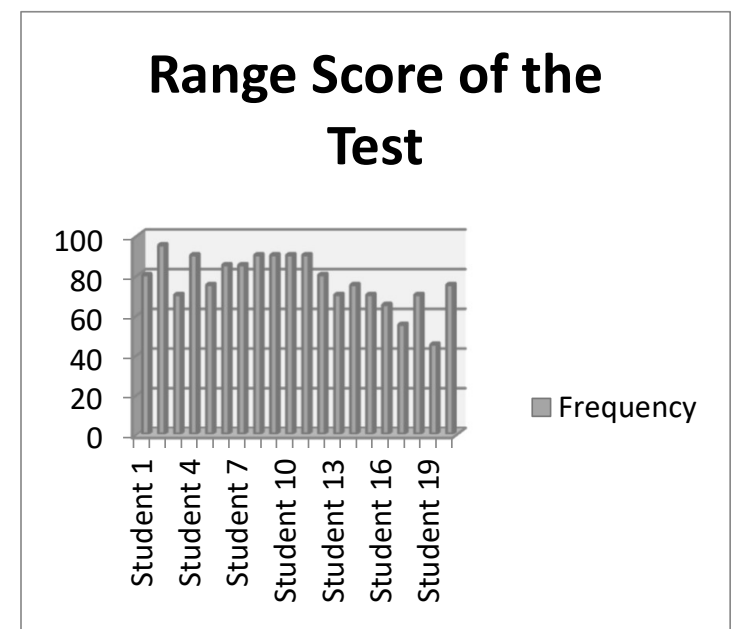

Sources: The data was gained by the writers, 2021
After describing the data by using histogram, the table of mastery level and counting the mean, the data was categorized by the standard mastering level by calculating frequency distribution that described how the result was. The score counted the mean. It can be seen how the average score of the class was.

The researcher did the result of the test in average and sum of the test as below:

$$
\text { Average score: } \begin{aligned}
X & =\frac{\sum X}{N} \\
X & =\frac{\sum 1545}{20}=77,25
\end{aligned}
$$

Analysis procedure

Step 1: Sum up the whole scores to obtain $\Sigma X($ the total scores $=1545)$

Step 2: Divide the result by $\mathrm{N}$ (the number of students $=20$ )

So, the average score's test in personal pronoun was 77.25.

Sum of the test who reached benchmarks

$$
\begin{gathered}
P=\frac{F}{N} \times 100 \% \\
P=\frac{17}{20} \times 100 \%=85 \% \\
\text { Analysis procedure }
\end{gathered}
$$

Step 1: Sum up the whole scores to obtain F (the total who gained benchmark $=17$ students)

Step 2: Divide the result by N (the number of students $=20$ ) 
After the researcher calculated the mean and sum of the student's score of understanding using personal pronouns, the researcher found that the students who reached benchmark score's test in personal pronouns was $85 \%$. Then, the participation of the students who did the test was gained 1545 from total scores of all the students who joined the test. Then the average of students' scores was 77.25 and the sum of the total scores was $85 \%$. It means that most of the students did well on the test and understood personal pronouns in reading text. In addition, the researcher describes the classification score in the chart below:

\section{Figure 4.2}

The Classification Score of the Test

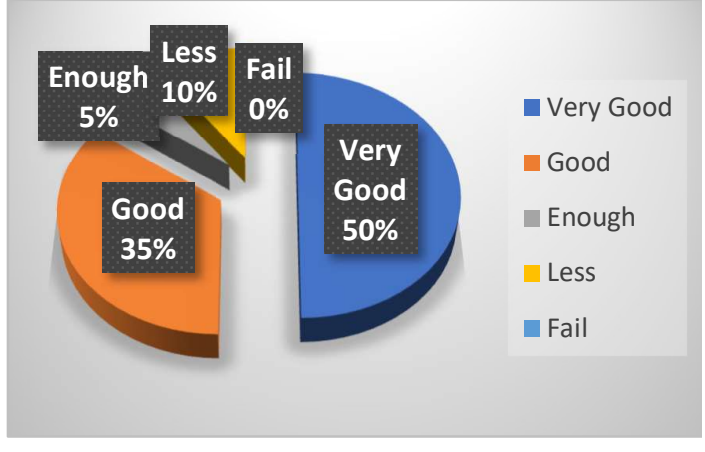

Based on the chart above, the researcher categorized the students' score of the personal pronoun test in five categories. They were very good, good, enough, less and fail. The students who got very good was 50\% which means 10 (ten) students, in GOOD category was 35\% students which means 7 (seven) students, ENOUGH category was $5 \%$ which means 1 (one) student and LESS category was $10 \%$ which means 2 (two) students. The total of the students were 20 students that contributed to the test of understanding personal pronouns in English reading text. In addition, to know the detail of the percentage of student's score of understanding personal pronouns, it can be seen in the table below:

Table 4.2

The percentage of the students' understanding of personal pronouns in English reading text

\begin{tabular}{|c|c|c|c|c|}
\hline \multirow{2}{*}{ No } & \multicolumn{2}{|c|}{ Classification } & Frequency & Percentage \\
\cline { 2 - 5 } & Score & $\begin{array}{c}\text { Ability } \\
\text { Level }\end{array}$ & $\begin{array}{c}\text { (100\%) } \\
\text { (students) }\end{array}$ & $50 \%$ \\
\hline 1 & $80-$ & $\begin{array}{c}\text { Very } \\
\text { Good }\end{array}$ & 10 & \\
\hline 2 & $66-79$ & Good & 7 & $35 \%$ \\
\hline 3 & $56-65$ & Enough & 1 & $5 \%$ \\
\hline 4 & $40-55$ & Less & 2 & $10 \%$ \\
\hline 5 & $30-39$ & Fail & 0 & 0 \\
\hline & & & $\mathbf{2 0}$ & \\
\hline
\end{tabular}

Using this table, the researchers knew how the students' understanding in using the personal pronouns. It could be good or not. Actually, the average score could present the students' abilities in the whole class. The score was the average score of all the students' scores. The absolute grading table had five levels of ability. They were VERY GOOD, GOOD, ENOUGH, LESS, and FAIL. It means that most of the students at SMPN 1 Singingi understood about personal pronouns in English, especially in reading text.

\section{CONCLUSION}

From previous findings and discussions, it presents some conclusions about the teachers' how the ability of the first grade students of SMPN 1 Singingi in personal pronouns in reading text was. From the data 
presentation and data analysis in chapter IV, it described that the total scores of the students' test was 1545 and the mean score range of the students' ability in using personal pronouns in reading text was 77.25. Based on the calculation, 10 students $(50 \%)$ were classified into VERY GOOD, 7 students (35\%) were classified into GOOD level, 1 student (5\%) was classified into ENOUGH level, 2 students $(10 \%)$ were classified into LESS level and none of the student was classified into FAIL level. In addition, the researcher concluded the personal pronoun in using reading text was categorized into GOOD level. There were 20 students of SMPN 1 Singingi who participated in this research.

\section{REFERENCES}

Asirun unung. (2008). The ability of the second year students in using indefinite Pronoun at MTs. Hidayatullah Lubuk dalam Siak. Unpublished Paper. Pekanbaru. Uin Suska

Amin, R. Eravelly. dkk. (2004). Grammar Builder. Cambridge: University Press

Arikunto, S. (2013). Prosedur Penelitian Suatu Pendekatan Praktik. Jakarta: PT Rineka Cipto

Arikunto, Suharsimi. (2007). DasarDasar Evaluasi Pendidikan. Jakarta: Bumi Aksara

Alsagoff, Lubna. (2008). A Visual Grammar of English-Revised Edition. Singapore: Pearson Education South Asia Pte Ltd.

Azar, Bety Scramfer. (1985). Fundamentals of English grammar. United States of America: Prentice-Hall Regent.

Azwar, S. (1996). Tes Prestasi Fungsi dan Pengembangan Pengukuran Prestasi Belajar. Yogyakarta: Pustaka Pelajar.
Azar, B.S. (1989). Understanding and Using English Grammar. New Jersey: Prentice-Hall.

Brown, H.D. (2004). Language Assessments Principles and Classroom Practices. USA: Pearson Edition, Inc.

Christensen, L.B. (2001). Experimental Methodology (8th edition). USA: A Pearson Education Company.

Creswell, J.W. (2007). Qualitative Inquiry \& Research Design (2nd edition). USA: Sage Publications, Inc.

Desmi, (2008). Student's ability in using Adjective Clause Unpublished Undergraduate Thesis. Pekanbaru: Faculty of Education and Teacher Training UIN Suska Riau.

Dixson, Robert, J. (2004). Grammar to Go 123: English Grammar Practice. USA: Pearson Education, Inc.

Eckerley, C.E., Eckerley, J.M (1973). A Comprehensive English Grammar, Longman Group Limited, London.

Evans, Virginia. (2003). English Grammar Book-Round Up. England: Pearson Education Limited.

Frank, M. (1972). Modern English Exercise for Non-Native Speaker Part 1: Part of Speech. New Jersey: Prentice-Hall.

Gerot L, Wignell P. (1994). Making Sense of Functional Grammar. Sydney: Stabler.

Harrys, D. P. (1969). Testing English as a Second Language. New York: McGraw- Hill Book Company.

Leech G, Deuchar M, Hoogenraad R. (1982). English for Today: A New Introduction. Hong Kong: Macmillan Education LTD.

Linse, Caroline, T. (2006). Practical English Language Teaching: Young Learners. Singapore: Singapore Press. 